\title{
The Influence of Starter Volume and Air Flowrate in Hospital Waste Water Treatment using Aerobic Fixed Film Biofilter Batch (AF2B) Reactor
}

\author{
Prayitno $^{\bowtie}$, Hadi Saroso, Sri Rulianah, Mita Prastika
}

DOI 10.15294/jbat.v6i1.7952

Jurusan Teknik Kimia, Politeknik Negeri Malang, J1. Soekarno Hatta No 9 Malang, Indonesia

\begin{tabular}{l} 
Article Info \\
\hline Article history: \\
Accepted \\
November 2016 \\
Approved \\
April 2017 \\
Published \\
June 2017 \\
\hline Keywords : \\
Starter \\
Acclimatization \\
Batch \\
Hospital \\
Waste water \\
AF2B \\
\hline
\end{tabular}

\begin{abstract}
BOD, COD, phenol and ammonia-free in the effluent of hospitals wastewater often exceed the quality standards. This was due to less optimal biological processes to degrade the pollutants. So we need an efforts to find optimal process conditions through the engineering process and the factors that affect the biodegradation of pollutants. On the other hand, AF2B reactor containing biofilter with bee nest shaped has a large specific surface area so as to maximize the biodegradation process of pollutants by microorganisms. While bacteria consortium consisting of several types of bacteria have a greater capacity than a single bacterium in the degradation of pollutants. The research aims to determine the effect of starter volume and air flowrate to decrease the concentration of pollutants $(\mathrm{BOD}, \mathrm{COD}$, phenol and ammonia-free) in AF2B reactor batch using a bacterial consortium. The research was conducted in three phase which are the making of growth curve, acclimatization and biodegradation of pollutants in an AF2B reactor batch using a bacterial consortium. The experiment variables are the starter volume $(85 \%, 75 \%, 65 \%$ in volume $)$, and the air flowrate (2.5; 5 ; and 7.5 liter/min). Materials used are hospital waste water and bacterial consortium. The experiment begins with setting up the AF2B reactor containing biofilter with bee nest shaped and then filled it with a starter from the acclimatization process on a given volume and followed by supplies of air at a certain flowrate. Then hospital waste water and $5 \%$ of nutrients were added till reach 10 liters of total volume in reactor. Samples were taken every 30 minutes for up to 360 minutes of biodegradation process. The samples were then analyzed its pollutants concentration (BOD, COD, phenol and ammonia-free). The BOD concentration was analyzed using Winkler bottles method, COD using open reflux method, while phenol and ammonia-free using UV-Vis spectrophotometry method. The results showed that the starter volume and air flowrate affect the decrease of pollutants concentration till reach quality standard, which at starter volume of $85 \%$, air flowrate of $7.5 \mathrm{liter} / \mathrm{min}$ and biodegradation time of $360 \mathrm{~min}$ can reduce the BOD, COD, phenol, and ammonia-free to $92 \%, 86 \%, 88 \%$ and $76 \%$ respectively.
\end{abstract}

\section{INTRODUCTION}

Hospital wastewater has become one of serious environmental issue in Indonesia. Around $54 \%$ of hospitals in Indonesia dispose the waste water to infiltration wells, while the hospital actually has their own waste water treatment (IPAL) which still has not worked optimally, therefore the effluent of IPAL still exceeds the quality standard (Anonim, 1995; Anonim, 2004;
Nasr \& Yazdanbakhsh, 2008, Prayitno et al., 2013). Hospital waste water contains infectious, pathogenic, biodegradative, and radioactive pollutants, where the pollutant is potentially causing pollution and health problems (Arifin, 2008). Several pollutants from hospital waste water which exceed the quality standard of the environment, are BOD, COD, phenol, free ammonia, and free chlorine (Nasr \& Yazdanbakhsh, 2008, Prayitno et al., 2013)).

(C) 2017 Semarang State University

\footnotetext{
${ }^{\square}$ Corresponding author:

Jurusan Teknik Kimia, Politeknik Negeri Malang,

J1. Soekarno Hatta No 9 Malang, Indonesia

E-mail: prayitno@polinema.ac.id
} 


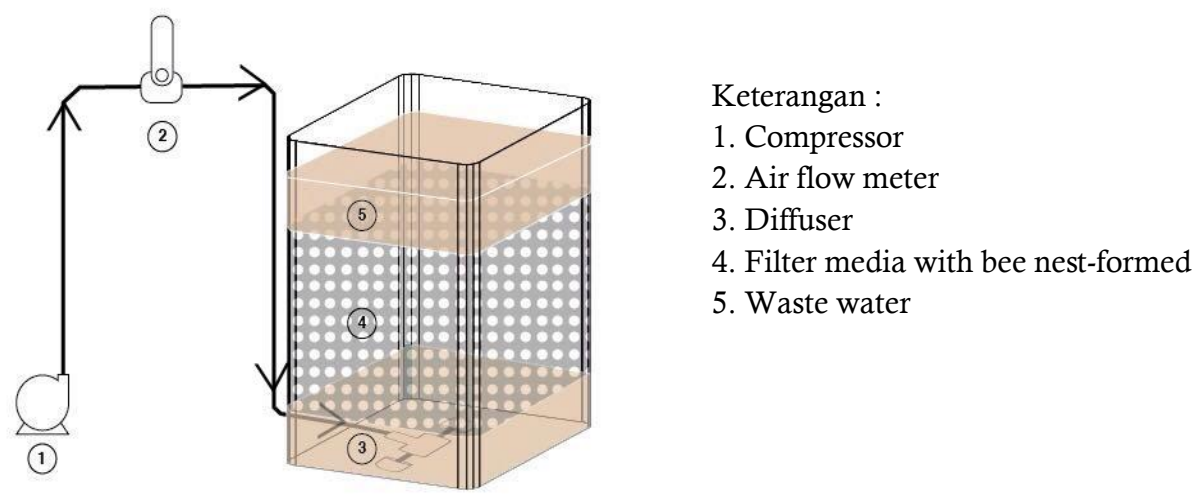

Figure 1. AF2B reactor

The less optimal works of IPAL in managing the waste water, especially in degrading the pollutants are caused by the less optimal operating condition, less appropriate microorganism types and less appropriate technology used (Djaja \& Maniksulistya, 2006).

Several technologies that used in hospital waste water treatment are: Activated Sludge Combined with Biological Contactor (Greentech, 2001), Anaerobic-Aerobic Fixed Film Bioreactor (A2F2B) (Rezaee et al., 2005), Submerged Membrane Bioreactor (SMB) (Wen et al., 2004), Combination of Up flow Anaerobic Fixed-Bed (UAF-B) and Suspended Aerobic Reactor (SAR) (Kocadagistan et al., 2005), up flow Anaerobic Sludge Blanket and Aerobic Sequential Batch Reactor (Farooqi et al., 2008). Nonetheless, these technologies have not been degrading the concentration of the pollutants optimally. Otherwise, AF2B reactor is a reactor filled with filter media as bacterial growth media. The filter media is made of plastic in bee nest form, making it has a wider surface area. The width of the filter area surface influences the pollutants degradation by microorganism (Tchobanoglous et al., 2003; Sridevi et al., 2012). Meanwhile, bacterial consortium has been proved in degrading the concentration of pollutant in waste water more effectively compared to single bacterium (Dey \& Mukherjee, 2010).

Several types of bacterial consortium for the waste water pollutants degradation process are Pseudomonas putida, Pseudomonas capica, Pseudomonas diminuta Nitrobacter sp, Citrobacter sp. (Suhendrayatna, 2001). Thereby, in order to achieve the maximum efficiency and optimization in degrading the concentration of pollutants in hospital waste water, there should be an alternative treatment technology started by the research of Aerobic Fixed Film Biofilter (AF2B) reactor and bacterial consortium in degrading the concentration of BOD, COD, phenol and free ammonia. That is why this research is aimed to discover the influence of starter volume (Vs) and air flowrate towards the degradation of pollutants (BOD, COD, phenol and free ammonia) in AF2B batch operating reactor.

\section{MATERIALS AND METHODS}

\section{Materials}

The experiment used $10 \mathrm{~L}$ plastic AF2B reactor, with bee nest formed filter media and a diffuser which was connected to a compressor. The filter media density is $0,125 \mathrm{~g} / \mathrm{cm}^{3}$ and its surface area is $150-240 \mathrm{~m}^{2} / \mathrm{m}^{3}$.

The materials used in this research were: hospital waste water and isolate of bacterial consortium, where the isolate contains 4 types of bacteria, including Pseudomonas capica, Pseudomonas diminuta, Bacillus sp, and Nitrobacter sp. The isolate bacterial consortium were obtained from the isolation of bacteria in hospital waste water prepared by Biotechnology Laboratory in PAU ITB.

\section{Methods}

This research involved three stages, first is making the bacterial consortium growth curve, acclimatization of bacterial consortium and biodegradation of pollutants in AF2B batch reactor.

The growth curve was created through several steps. First, $1 \mathrm{ml}$ of isolate bacterial consortium and $200 \mathrm{ml}$ of hospital waste water were poured inside the erlenmeyer, then the erlenmeyer was covered tightly with sterile gauze plug. Next, 


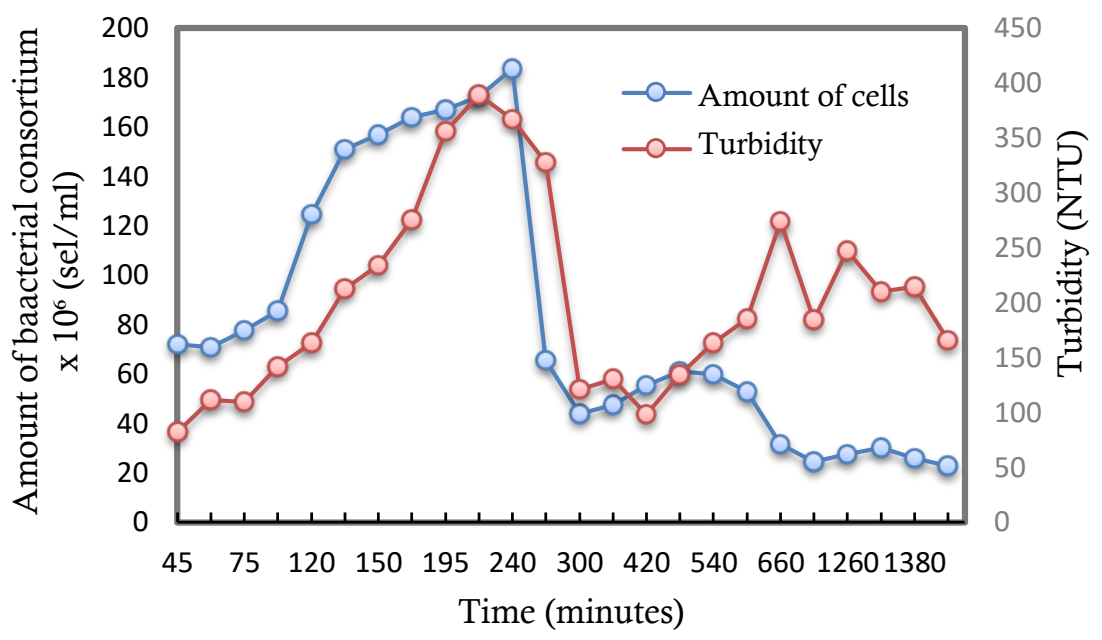

Figure 2. Bacterial consortium growth curve

the solution of bacteria inside of erlenmeyer was shaken using incubator shaker for 48 hours. Samples of the culture were taken every 1 hour for up to 12 hours. The turbidity was measured using UV-Vis spectrophotometer, and the number of bacterial consortium was measured using haemacytometer.

Acclimatization process of bacterial consortium was started by taking 150 gr isolate of bacterial consortium and added into the tub. Aquadest was added and air was supplied inside the tub. Then, $5 \%(\mathrm{v} / \mathrm{v})$ of nutrition was given into the tub and $\mathrm{pH}$ of the starter's solution was measured. Next, $10 \%$ of (v/v) hospital waste water was added gradually every day until the total volume reached 10 liter. Bacterial consortium growth was then observed by measuring MLSS value in starter solution.

Waste water treatment process using $\mathrm{AF} 2 \mathrm{~B}$ reactor was started by preparing AF2B filled with bee nest filter formed. A diffuser was connected from AF2B reactor under the filter media to the compressor to supply an air especially oxygen for bacterial consortium. Starter of bacterial consortium from acclimatization process was then feed into AF2B reactor at certain volume (the volume variables were $65 \%, 75 \%$ and $85 \%$ of total volume) followed by supplying air from compressor at certain flowrate (flowrate variables were 2.5, 5, and 7 liter/minute). Once the starter has grown well, the hospital waste water was then added into $\mathrm{AF} 2 \mathrm{~B}$ reactor as a substrate containing pollutants such as BOD, COD, phenol and free ammonia at certain concentration, substrate addition was continued till the total volume in the reactor reached 10 liter. Besides that, $5 \%$ of nutrition which consists of glucose, ammonium sulphate and $\mathrm{KH}_{2} \mathrm{PO}_{4}$ ratio of 100:5:1 was added into the reactor.

Samples were taken from AF2B reactor every 30 minutes for up to 360 minutes. The samples were analyzed using APHA standard method where BOD was analyzed using Winkler bottle, COD analyzed using open reflux method, phenol and free ammonia analyzed using spectrophotometry UV-Vis, and MLSS (Mixed Liquid Suspended Solid) analyzed using gravimetric analysis (APHA, AWWA, WPCF, 1995).

\section{RESULTS AND DISCUSSIONS}

The result of the experiment in the determination of bacterial consortium growth curve shows that bacterial consortium experiences relatively good growth seen from the number of living cells every time where the growth of bacterial consortium is following the theoretical patterns of bacteria growing phases which are stagnant phase, growth phase, stationary phase, and death phase (Grady et al, 1999; Metcalf \& Eddy revised by Tchobanoglous et al., 2003). Growth phase occurred in the $90^{\text {th }}$ minute to $240^{\text {th }}$ minute. It means, the bacterial consortium experienced maximum growth in the $240^{\text {th }}$ minute (4 hours).

The experiment results of bacterial consortium acclimatization show that bacterial consortium were grew well in the hospital waste water media where the number of bacteria cells increases along with the increasing volume of waste water. Thus, the bacterial consortium (starter) is surely able to be used to treat or degrade the pollutants in hospital waste water. 


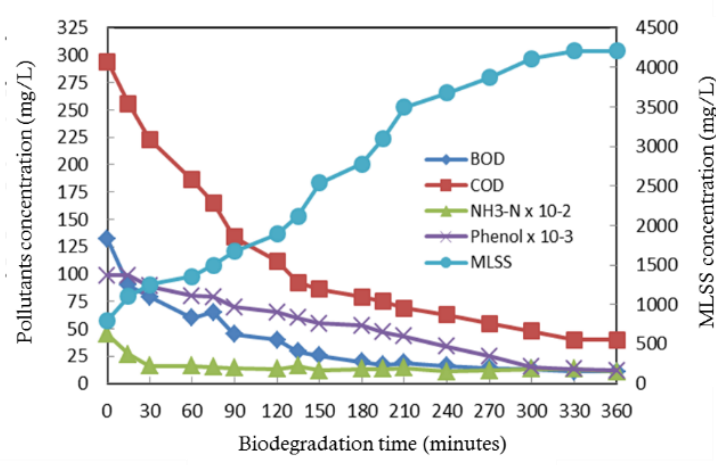

(a)

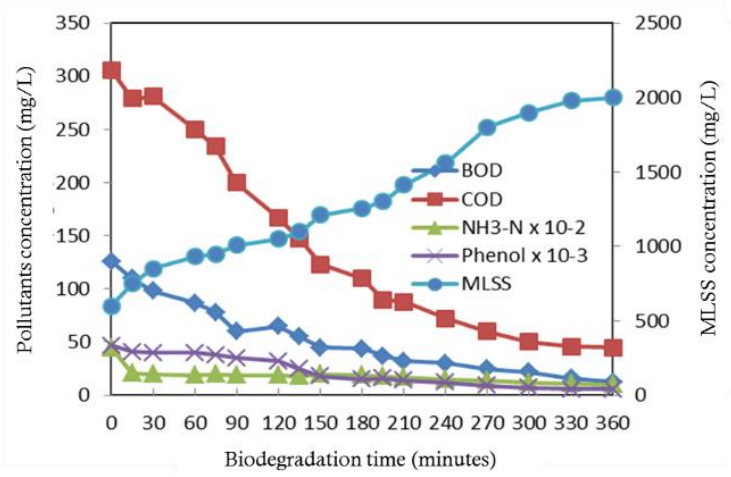

(b)

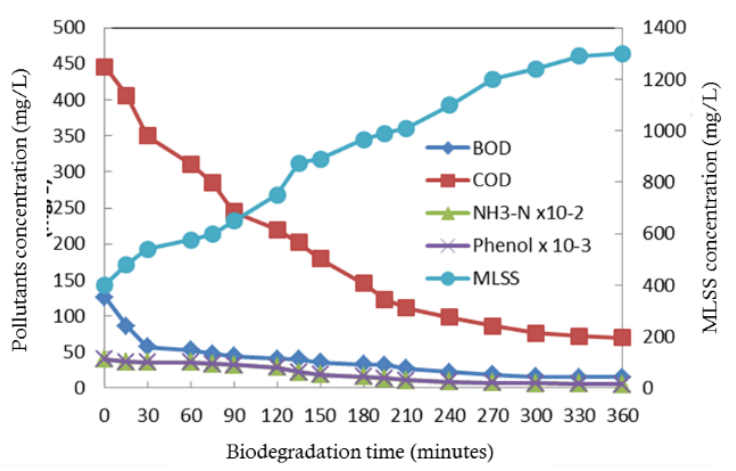

(c)

Figure 3. Pollutants Concentration in AF2B reactor at different starter volume (Vs) with air flowrate of 7.5 liter/minute.(a). Vs: $85 \%$ (b). Vs: $75 \%$ (c). Vs: $65 \%$

Pollutants biodegradation experiment in $\mathrm{AF} 2 \mathrm{~B}$ reactor at different starter volume shows that the pollutants concentration (BOD, COD, phenol and free ammonia) in the waste water decrease along with the longer biodegradation time. In the other hand, the concentration of MLSS increases with the longer biodegradation time, where MLSS is the parameter of the total of bacterial consortium.

Figure 3 shows that the decrease of pollutants concentration (BOD, COD, phenol and free ammonia) occurred gradually, when from the $30^{\text {th }}$ minute until $240^{\text {th }}$ minute, there were a significant decrease, while in $270^{\text {th }}$ until $360^{\text {th }}$, the pollutants concentration remain constant. This condition is due to the bacterial consortium was still adapting with its environment at the first 15 minutes, while from $30^{\text {th }}$ minute until $240^{\text {th }}$ minute, bacterial consortium already had the ability to degrade the substrates (BOD, COD, phenol and free ammonia) maximally along with the growth. In the other side, from $270^{\text {th }}$ to $360^{\text {th }}$ minute, the biodegraded pollutants getting smaller and remain constant due to a limited number of the substrate.

The decreasing amount of pollutants concentration in biodegradation process can be seen from the increasing of MLSS concentration, where the result of pollutants biodegradation (BOD,
COD, phenol and free ammonia) process is a formation of new cells from bacterial consortium, water, gas, and energy (Tchobanoglous et al., 2003; Nair et al., 2008). Therefore, the longer the biodegradation process will increase the number of biodegraded pollutants by bacterial consortium, resulting many new cells produced from bacterial consortium. The existence of bacterial consortium is shown by a thicker biofilm layer deposited on the surface of bee nest formed biofilter. Kaplan et al. (2003) explained that the formation of new cells as a result of biodegradation process on the surface of biofilter involved 4 steps, consecutively they are initial attachment, irreversible attachment, maturation 1, maturation 2 and dispersion.

Figure $3 \mathrm{a}$ and Figure $3 \mathrm{c}$ show that the higher the starter volume added inside the AF2B reactor, the higher the decrease of pollutants concentration. Degradation time of 360 minutes with $85 \%$ of starter volume can decrease the pollutants concentration as follow, BOD (92\%), COD (86\%), phenol (88\%) and free ammonia (76\%). Meanwhile, 65\% starter volume successfully decreases pollutants concentration, including BOD (88\%), COD (84\%), phenol (86\%) and free ammonia (76\%). It is caused by the higher the starter volume, the more bacterial consortium 


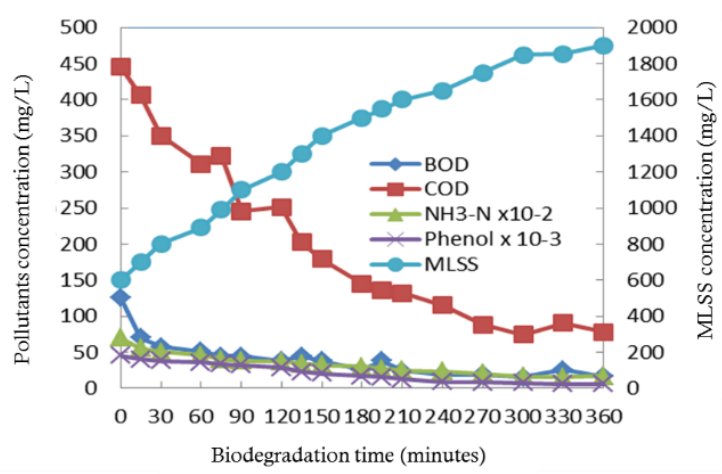

(a)

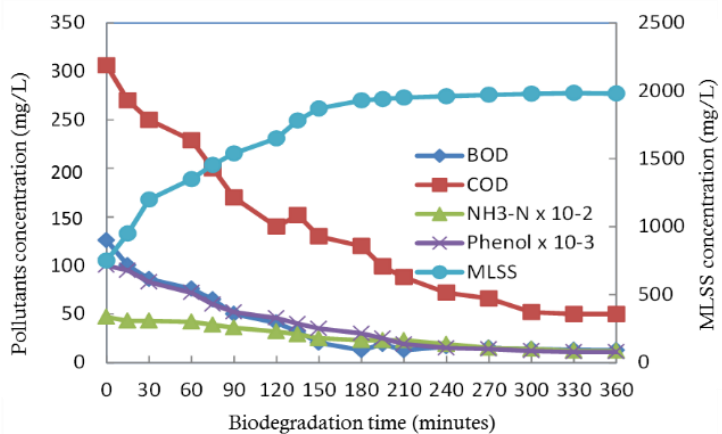

(b)

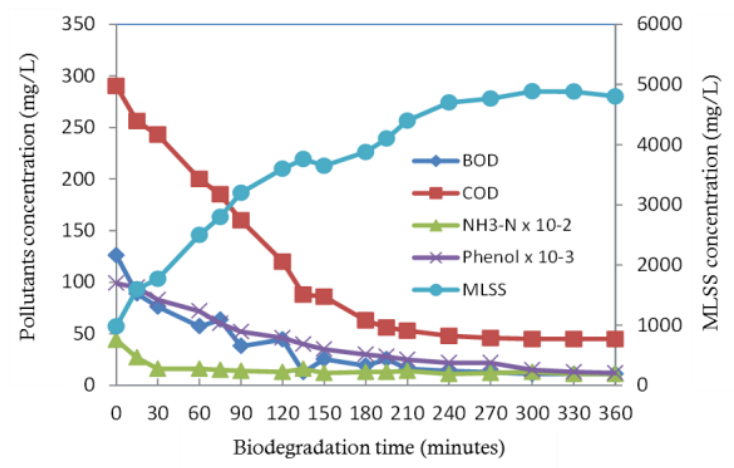

(c)

Figure 4. Pollutants Concentration in AF2B reactor at different starter volume (Vs) with air flowrate of 5 liter/minute.(a). Vs: $85 \%$ (b). Vs: $75 \%$ (c). Vs: $65 \%$

degrading the pollutants, resulting decrease of pollutants concentration in waste water (Harvey et al., 2011; Dey \& Mukherjee, 2010).

In the aerobic process, the rates of pollutants biodegradation by microorganisms is influenced by temperature, $\mathrm{pH}$, initial concentration, types of microorganism, residence time, nutrition, and substrate - microorganism ratio (Tchobanoglouset al., 2003; Metcalf \& Eddy revised by Tchobanoglouset al., 2003).

Experimental study using 5 liter/minute of air flowrate at each starter volume can be seen in Figure 4. Figure 4 shows that the longer biodegradation time, the higher decrement of pollutants concentration, and the higher increment in MLSS concentrations. According to Figure 4a and Figure $4 \mathrm{c}$, it was obtained that in the $360^{\text {th }}$ minute of biodegradation time using $85 \%$ starter volume, there is a decreasing concentration of BOD (91\%), COD (84\%), phenol $(88 \%)$ and free ammonia $(75 \%)$. However, the addition of $65 \%$ starter volume made a decrease pollutants concentration in the details of BOD (87\%), COD $(83 \%)$, phenol $(87 \%)$ and free ammonia $(83 \%)$. It shows that starter volume influences the decrease of pollutants concentration in waste water.
AF2B reactor is filled with bee nest-formed bio-filter which has large surface area (150 - 240 $\mathrm{m}^{2} / \mathrm{m}^{3}$ ). This make the higher the starter volume, the more bacterial consortium covering the surface of biofilter to form biofilm which is functioned for pollutants degradation in waste water (Harveyet al., 2011).

Bacterial consortium consists of Pseudomonas capica, Pseudomonas diminuta, Bacillus $s p$, and Nitrobacter sp. The role of Pseudomonas capica, Pseudomonas diminuta and Bacillus $s p$ is to biodegrade $\mathrm{BOD}, \mathrm{COD}$ and phenol to be $\mathrm{CO}_{2}$, $\mathrm{H}_{2} \mathrm{O}$, energy and new cells. Meanwhile, Nitrobacter $s p$ has a role in degrading free ammonia into $\mathrm{N}_{2}$, $\mathrm{H}_{2} \mathrm{O}$, energy and new cells (Sridevi et al., 2012; Tchobanoglous et al., 2003).

The experiment results of pollutants biodegradation in AF2B reactor using 2 liter/minute of air flow rates in different addition of starter volume are shown in Figure 5. Figure 5 shows that the decrement of pollutants concentration has the same patterns to the previous experiment, where the longer the biodegradation process the higher the decrement of pollutants concentration (BOD, COD, phenol and free ammonia), otherwise it increase the MLSS concentrations. 


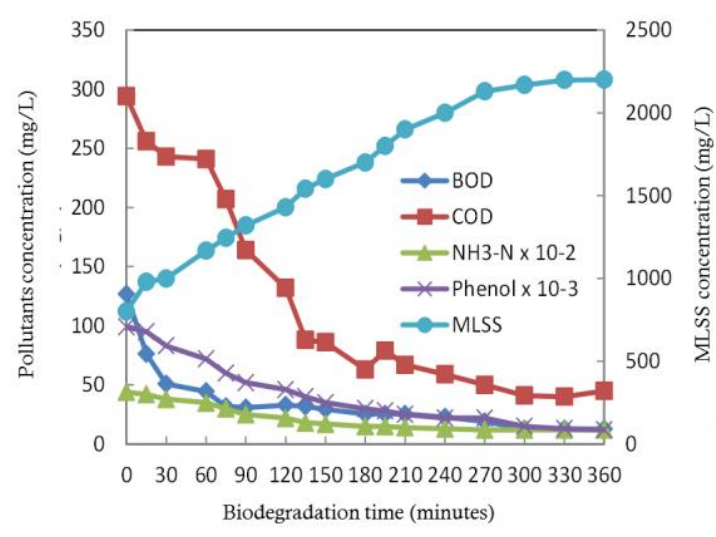

(a)

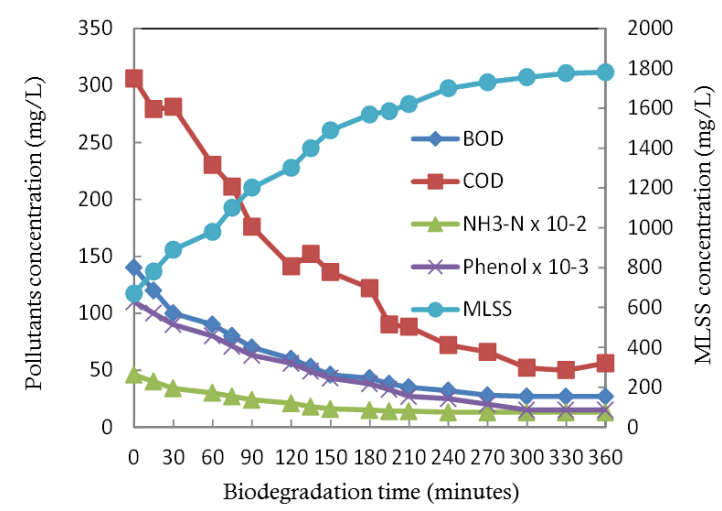

(b)

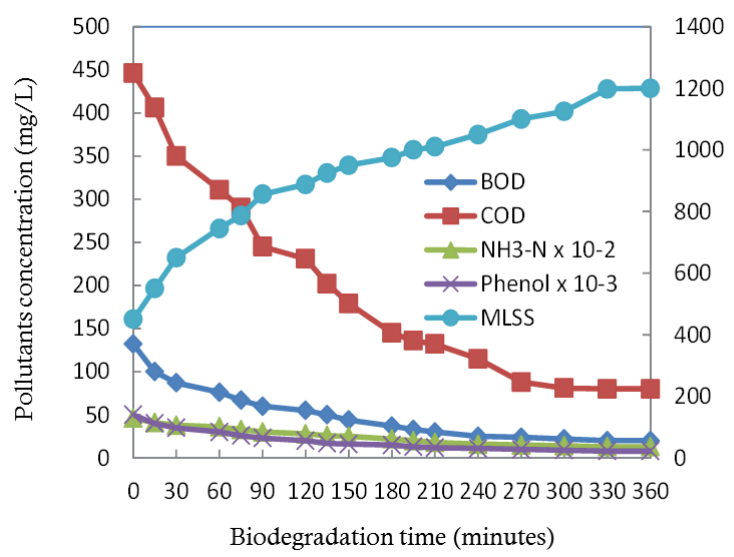

(c)

Figure 5. Pollutants Concentration in AF2B reactor at different starter volume (Vs) with air flowrate of 2.5 liter/minute.(a). Vs: $85 \%$ (b). Vs: $75 \%$ (c). Vs: $65 \%$

Table 1. Pollutants concentration before and after the treatment in AF2B reactor at starter volume (Vs) of $85 \%$.

\begin{tabular}{|c|c|c|c|c|c|}
\hline \multirow[b]{2}{*}{ Parameter } & \multirow[b]{2}{*}{$\begin{array}{l}\text { Pollutants } \\
\text { concentration } \\
\text { in influent }\end{array}$} & \multicolumn{3}{|c|}{ Pollutants concentration in effuent } & \multirow{2}{*}{$\begin{array}{c}\text { Quality } \\
\text { Standard of } \\
\text { Hospital waste } \\
\text { water }\end{array}$} \\
\hline & & $\begin{array}{c}\mathrm{Q}_{\mathrm{ud}}=7.5 \\
\text { liter/minute }\end{array}$ & $\begin{array}{c}\mathrm{Q}_{\mathrm{ud}}=5 \\
\text { liter/minute }\end{array}$ & $\begin{array}{c}\mathrm{Q}_{\mathrm{ud}}=2.5 \\
\text { liter/minute }\end{array}$ & \\
\hline $\mathrm{BOD}(\mathrm{mg} / \mathrm{L})$ & $126-132$ & 11 & 11 & 13 & 30 \\
\hline $\mathrm{COD}(\mathrm{mg} / \mathrm{L})$ & $290-294$ & 40 & 45 & 45 & 80 \\
\hline Phenol (mg/L) & 0.099 & 0.012 & 0.012 & 0.012 & 0.01 \\
\hline $\begin{array}{l}\text { Free ammonia } \\
(\mathrm{mg} / \mathrm{L})\end{array}$ & $0.44-0.45$ & 0.11 & 0.11 & 0.12 & 0.1 \\
\hline
\end{tabular}

Figure $5 \mathrm{a}$ shows that in biodegradation time of $270^{\text {th }}-360^{\text {th }}$ minute, there is a stagnant process of pollutants biodegradation. At this time range, the decrement of pollutants concentration such as BOD, COD, phenol and free ammonia were subsequently in the level of $90 \%, 85 \%, 88 \%$, and $73 \%$. Therefore, the higher starter volume used the higher the decrement of pollutants concentration, thus; the starter volume influences the decrease of pollutants concentration.

If this results is compared to Figure 3, where the experiment use 7.5 liter/minute of air flow rates, it can be concluded that the higher air flowrate into AF2B reactor, the faster pollutants biodegradation process. Later, it will decrease pollutants concentration in waste water. It is because the more air flows, the more air consumed by bacterial consortium for the pollutants biodegradation process causing faster growth of bacterial consortium. It means the higher decrement of pollutants concentration in waste water.

Table 1 shows that the hospital waste water treatment using $\mathrm{AF} 2 \mathrm{~B}$ batch reactor containing 
bacterial consortium is effective in decreasing the concentration of pollutants in waste water. Where biodegradation process using air flowrate of 7.5 liter/minute and $85 \%$ of starter volume, there was a decrement of pollutants such as BOD (92\%), COD $(86 \%)$, phenol $(88 \%)$ and free ammonia $(76 \%)$. Besides, pollutants concentration resulted from treatment process (effluent) was still under the quality standard of hospital waste water.

In other side, the treatment process of hospital waste water using the Anaerobic- Aerobic Fixed Film Biofilter (A2F2B) process can decrease the concentration of COD (82\%) and coliform $(90 \%)$ (Rezaee et al., 2005). The process of Submerged Membrane Bioreactor (SMB) can decrease BOD (48\% -70\%) and coliform (50\% - 75\%) (Wen et al., 2004). Even, the combination of Up flow Anaerobic Fixed-Bed (UAF-B), Suspended Aerobic Reactor (SAR) and microfiltration can decrease COD (94 - 98\%) (Kocadagistan et al., 2005). Meanwhile, the Up flow Anaerobic Sludge Blanket (UASB) reactor can decrease the concentration of phenol to $80 \%$ in 40 days, while Submerged Biofilter Reactor (SBR) can decrease it to $95 \%$ in only 30 days. It means, bacterial consortium in AF2B reactor has high capability in decreasing pollutants concentration hospital waste water like BOD, COD, phenol and free ammonia.

\section{CONCLUSION}

Based on the result analysis of the experiment, it can be concluded that flow rate and starter volume influence the decrease of pollutants concentration (BOD, COD, phenol and free ammonia) in hospital waste water, where biodegradation process using 7.5 liter/minute air flow rates, $85 \%$ starter volume, and 6 hours degradation process resulting biggest decrease of pollutants concentration, specifically to BOD, COD, phenol and free ammonia in the level of $92 \%$, $86 \%, 88 \%$ and $76 \%$ respectively.

\section{ACKNOWLEDGEMENT}

In this occasion, the researcher is going to thank the Kemenristek Republik Indonesia c.q Direktur Jenderal Penguatan dan Pengembangan Riset which has been providing research funds through Penelitian Unggulan Perguruan Tinggi (PUPT) program. Besides, the researcher would like to thank Politeknik Negeri Malang and All staffs of Chemical Engineering Department which has helped this research.

\section{REFERENCES}

Anonim. 1995. Baku Mutu Limbah Cair bagi Kegiatan Rumah Sakit. Keputusan Menteri Lingkungan Hidup 1995. No. 58/MENLH/12/1995. Kementerian Negara Lingkungan Hidup. Jakarta.

Anonim. 2004. Profil Kesehatan Indonesia. Departemen Kesehatan RI. Jakarta.

APHA, AWWA, WPCF, 1995. Standart Methods for The Examination of Water and Wastewater, Washington DC.

Arifin, M. 2008. Pengaruh Limbah Rumah Sakit Terhadap Kesehatan. FKUI. Jakarta.

Dey, S., Mukherjee, S. 2010. Performance and Kinetic Evaluation of Phenol Biodegradation by Mixed Microbial Culture in a Batch Reactor. International Journal of Water Resources and Environmental Engineering. 2(3) : 40-49.

Djaja, I M., Maniksulistya, Dwi. 2006. Gambaran Pengelolaan Limbah Cair di Rumah Sakit X Jakarta. Jurnal Makara Kesehatan. 10(2) : 89 - 95.

Farooqi, I. H., Basheer, F., Ahmad, T. 2008. Studies on Biodegradation of Phenols and m-Cresols by Upflow Anaerobic Sludge Blanket and Aerobic Sequential Batch Reactor. Global NEST Journal. 10(1) : 3946.

Grady, C. P., Leslie, L., Glen, T. Daigger, D., Henry, C. L. 1999. Biological Wastewater Treatment. Marcel Dekker. New York.

Greentech, Co. Ltd. 2001. Treatment of Hospital Wastewater Using Activated Sludge Combined With Biological Contactor. Website; http://greentechvietnam.com/ thuvien/paper/paper-DongThap.pdf.

Harvey, G., Hasibul, H., Dipesh, D. 2011. Biofilm Fixed Film System. Water ISSN 2073 4441. 3: 843 - 868.

Kaplan, J. B., Ragunath, C., Ramasubbu, N., Fine, D. H. 2003. Detachment of Actinobacillus actinomycetemcomitans Biofilm Cells by an Endogenous b-Hexosaminidase Activity. Jurnal of Bacteriology. 185(16) : 4693-4698.

Kocadagistan, B., Kocadagistan, E., Topcu, N., Demircioğlu, N. 2005. Wastewater 
Treatment with Combined Upflow Anaerobic Fixed-Bed and Suspended Aerobic Reactor Equipped with a Membrane Unit. Process Biochemistry. 40(1) : 177-182.

Metcalf \& Eddy, revised by Tchobanoglous, G., Burton, F. L., Stensel, H.D. 2003. Wastewater Engineering: Treatment and Reuse, $4^{\text {th }}$ Edition, Mc Graw - Hill, New York.

Nair, C. I., Jayachandran, K., Shashidhar, S. 2008. Biodegradation of Phenol. African Journal of Biotechnology. 7(25) : 4951-4958.

Nasr, M. M., Yazdanbakhsh, A. R. 2008. Study on Wastewater Treatment Systems in Hospitals of Iran. Iranian Journal of Environmental Health. Science and Engineering. 5(3) : 211-215.

Prayitno, Kusuma, Z., Yanuwiadi, B., Laksmono, R. W. 2013. Study of Hospital Wastewater Characteristic in Malang City. Research Inventy: International Journal of Engineering and Science. 2(2) : 13-16.

Rezaee, A., Ansari, M., Khavanin, A., Sabzali, A., Aryan, M. M. 2005. Hospital Wastewater
Treatment Using an Integrated Anaerobic Aerobic Fixed Film BioReactor. American Journal of Environmental Sciences. 1(4) : 259-263.

Sridevi, V., Lakshmi, M. V. V. C., Manasa, M. Sravani, M. 2012. Metabolic Pathways for the Biodegradation of Phenol. International Journal of Engineering Science \& Advanced Technology. 2(3) : 695-705.

Suhendrayatna. 2001. Bioremoval Logam Berat Dengan Menggunakan Microorganisme: Suatu Kajian Kepustakaan. Seminar on Air Bioteknologi untuk Indonesia Abad 21, Sinergy Forum - PPI Tokyo Institute of Technology.

Tchobanoglous, G. F. L., Burton, B., Stensel, H. D. 2003. Wastewater Engineering Treatment and Reuse, Mc Graw-Hill Book Co, New York.

Wen, X., Ding, H., Huang, X., Liu, R. 2004. Treatment of Hospital Wastewater using a Submerged Membrane Bioreactor. Process Biochemistry. 39(11) : 1427-1431. 